\title{
Age and growth of the dog snapper Lutjanus jocu (Bloch \& Schneider, 1801) in Abrolhos Bank, Northeastern Brazil
}

\author{
Marília Previero $^{1}$, Carolina V. Minte-Vera ${ }^{1}$, Matheus Oliveira Freitas ${ }^{2}$, \\ Rodrigo Leão de Moura ${ }^{3}$ and Claudenice Dei $\operatorname{Tos}^{1}$
}

We determined the age and growth of the dog snapper (Lutjanus jocu), caught in the region of Abrolhos Bank, Bahia State, by the fishermen from coastal communities of Prado, Alcobaça, Caravelas, and Nova Viçosa. We examined 205 sectioned otoliths of fish caught by harpoon, longline, hand line, and gill nets (14.5 to $79.5 \mathrm{~cm}$ fork length). The formation of each ring was considered annual. The sectioned otoliths showed between 0 and 29 rings. Nearly half of the analyzed specimens had between 0 and 7 rings ( 88 of 205). Fish caught with nets in the estuarine region were the juvenile, while fish caught with lines and harpoons were the oldest. Two von Bertalanffy growth models were fitted to length-at-age data: one assuming constant variance of length-at-age (SVB) and another assuming constant coefficient of variation, i.e. variance increasing as a function of average size (CVVB). The SVB estimates were $L_{\infty}=87.82 \mathrm{~cm}, K=0.10$, and $t_{0}=-1.486$ and the CVVB estimates were $L_{\infty}=117.60 \mathrm{~cm}, K=0.06$, and $t_{0}=-2.470$. The largest $L_{\infty}$ values estimated by the CVVB model are supported by reports from the literature of larger animals occurring in the deeper outer shelf of Abrolhos Bank. Growth parameters were also estimated for males and females separately (SVB model) $\left(L_{\infty}=92.80 \mathrm{~cm}, K=0.099\right.$, and $t_{0}=-1.680$ for males, and $L_{\infty}=82.10 \mathrm{~cm}, K=0.105$, and $t_{0}=-1.570$ for females).

Foi determinada a idade e o crescimento do dentão (Lutjanus jocu) capturado na região do Banco dos Abrolhos, Bahia, pelos pescadores das comunidades costeiras de Prado, Alcobaça, Caravelas e Nova Viçosa. Foram examinados 205 otólitos seccionados de peixes capturados por arpão, espinhel de fundo, linhas e redes de emalhe (14,5-79,5 cm comprimento furcal). A formação de cada anel foi considerada anual. Os otólitos seccionados apresentaram entre 0 e 29 anéis. Cerca de metade dos espécimes analisados teve entre 0 e 7 anéis ( 88 de 205). Os peixes capturados com redes na região estuarina foram os mais jovens enquanto os peixes capturados com arpões e linha foram os mais velhos. Dois modelos de crescimento de von Bertalanffy foram ajustados aos comprimentos individuais: um assumindo variância constante do comprimento em cada idade (SVB) e outro assumindo coeficiente de variação constante, isto é variância aumentando em função do tamanho médio (CVVB). As estimativas SVB foram $\left(L_{\infty}=87,82 \mathrm{~cm}, K=0,105 \mathrm{e} t_{0}=-1,486\right)$ e as estimativas CVVB foram $L_{\mathrm{o}}=117,60 \mathrm{~cm}, K=0,060$ e $t_{0}=-2,470$ ). Os maiores valores de $L_{\infty}$ estimados pelo modelo CVVB são sustentados por relatos da literatura de grandes animais encontrados em áreas mais profunda do Banco dos Abrolhos. Os parâmetros de crescimento também foram estimados para machos e fêmeas separadamente (modelo SVB), $\left(L_{\infty}=92,80 \mathrm{~cm}, K=0,099\right.$ e $t_{0}=-1,680$ para machos e $L_{\infty}=82,10 \mathrm{~cm}, K=$ 0,105 e $t_{0}=-1,570$ para fêmeas).

Key words: Lutjanidae, Otoliths, Reef fisheries.

\footnotetext{
${ }^{1}$ Universidade Estadual de Maringá, Núcleo de Pesquisas em Limnologia, Ictiologia e Aquicultura (Nupélia). Av. Colombo 5790, Bloco H-90, 87020-900 Maringá, PR, Brazil.mahpreviero@gmail.com, cminte@nupelia.uem.br, claudenicedeitos@uol.com.br

${ }^{2}$ Grupo de Pesquisa em Ictiofauna, Museu de História Natural Capão da Imbuia, Laboratório de Ictiologia. Rua Professor Benedito Conceição, 407, 82810-080 Curitiba, PR, Brazil.serranidae@gmail.com

${ }^{3}$ Universidade Estadual de Santa Cruz, Departamento de Ciências Biológicas e Programa de Pós-Graduação em Ecologia e Conservação da Biodiversidade. Rodovia Ilhéus-Itabuna, km 16, 45662-900 Ilhéus, BA, Brazil.moura.uesc@gmail.com
} 


\section{Introduction}

The dog snapper Lutjanus jocu (Bloch \& Schneider, 1801) occurs in tropical waters of the Western Atlantic from Massachusetts (USA) to Northeastern Brazil (Allen, 1985) and was recently reported for the Mediterranean Sea (Vacchi et al., 2010). This species is very important in fisheries, like most species of the family Lutjanidae. For example, the snappers accounted for $38 \%$ of the catch in the region of Porto Seguro, Southern Bahia State (Brazil) (Costa et al., 2003; data from 1997 to 1999). The exploitation of L. jocu in Northeastern Brazil began in 1978 (Frédou \& Ferreira, 2005) and is currently one of the main species in the artisanal and small and medium scale fisheries in the region, with 665 tons landed in 2005 (IBAMA, 2007). In 2005, 0.6\% (293 tons) of the total catches in Bahia State was dog snappers (IBAMA, 2007). For the districts in the region of Abrolhos Bank (Prado, Alcobaça, Caravelas, and Nova Viçosa), 56 tons of dog snappers were landed in 2002 (IBAMA, 2007). The dog snapper in Brazil, however, seems to be exploited to its maximum potential (Vasconcellos et al., 2007).

Throughout the Northeastern Brazilian coast Lutjanus jocu lives in mangroves and estuaries (individuals smaller that 7 $\mathrm{cm}$ ), on inner-shelf habitats (individuals ranging 10-30 cm) and in mid-shelf reefs (individuals larger than $40 \mathrm{~cm}$ ) (unpublished data). Juvenile specimens are also found in interreefal habitats with mixed algae, small rocks and sediment, at depths of 4-8 m. Adults ranging $26-30 \mathrm{~cm}$ are found mainly at depths less than $15 \mathrm{~m}$ (unpublished data). The spawning season of L.jocu is winter to spring; maturity is reached from $30.5 \mathrm{~cm}$ in females and $26.6 \mathrm{~cm}$ in males (Freitas et al., 2011). Other biological aspects of the species have been studied in Brazil, such as age and growth by Rezende \& Ferreira (2004) and diet by Monteiro et al., (2009). According to the latter authors, L. jocu feeds on many families of crustaceans, mollusks, and teleosts.

In Brazil, snappers are frequent targets of fisheries, yet there is still a considerable lack of ecological information on most species (Moura \& Lindeman, 2007). Knowledge of the age structure and growth pattern of a population, as well as differences between sexes, are prerequisites for understanding the longevity, growth rates, mortality, age at recruitment and sexual maturity of fish under exploitation, which are important information for the best management of fisheries (Lai et al., 1996; Haddon, 2001). This study aimed to estimate the von Bertalanffy growth parameters for Lutjanus jocu from otolith readings. Our results will contribute to the understanding of the growth dynamics of this species in the region of Abrolhos Bank.

\section{Material and Methods}

This study was carried out in the main fisheries landing spots in the Abrolhos region, Bahia State, a wide portion $\left(46,000 \mathrm{~km}^{2}\right)$ of the continental shelf with depths rarely exceeding $30 \mathrm{~m}$ and a shelf edge at about $70 \mathrm{~m}$ depth (16 $40^{\circ}$ $19^{\circ} 40^{\prime} \mathrm{S} 39^{\circ} 10^{\prime}-37^{\circ} 20^{\prime} \mathrm{W}$ ) (Fig. 1). The region comprises the largest and richest coralline reefs in the South Atlantic (Leão et al., 2003), with nearly 300 species of fish and 20 species of reef building corals, as well as an extensive mosaic of algal bottoms, mangrove forests, beaches, and vegetated sandbanks. Nearly 20,000 artisanal fishermen operate in the Abrolhos Bank, but the region's fisheries are poorly known and were not included in recent revisions of reef fisheries in Northeastern Brazil (Frédou et al., 2009a, 2009b).

Specimens of Lutjanus jocu were obtained between May 2005 and April 2007 from the reef fisheries' fleet that operates with harpoons, hand lines, long lines, and gillnets in the Cities of Prado, Alcobaça, Caravelas, and Nova Viçosa. A sample of 573 fishes was measured and weighted (Fig. 2), with a subsample of 205 individuals by length class taken for ageing (Lai et al., 1996). Length and weight data from each fish were recorded to the nearest $\mathrm{mm}$ and $\mathrm{g}$, respectively. In order to increase the number of individuals in the smallest length classes, additional sampling with gillnets was performed in the estuary located between Caravelas and Nova Viçosa. The sagittae otoliths were removed, washed in water and preserved dry in envelopes (Secor et al., 1991). Right and left otoliths were inspected for potential problems (e.g., breaking during sampling). Right otoliths were chosen for reading with a total sub-sample of 205 otoliths. Preparation and processing of otoliths followed Secor et al. (1991). Whole otoliths were weighed and read twice (by the first author) under a stereomicroscope with transmitted light. After this preliminary reading, otoliths were embedded in resin, cut and fixed on glass slides with standard procedures (e.g., ManickchandHeileman \& Philipp, 1996; Newman, 2002). After embedding, the otoliths were sectioned in their central region using a diamond saw (Buehler-Isomet). Successive cuts were made with varying thicknesses of $1.1 \mathrm{~mm}$ in the largest otolith to 1.3 $\mathrm{mm}$ in the smallest.

The counting of otolith rings (opaque bands) in sectioned otoliths was performed using a stereomicroscope with transmitted light. All sectioned otoliths were read twice by the same reader (first author), with readings separated by more than one month (Fig. 3). The precision between two readings was computed using the index Average Percent Error (APE) by Beamish \& Fournier (1981).

$$
\text { (1) } A P E=\frac{1}{n} \sum_{j=1}^{n}\left[\frac{1}{r} \sum_{i=1}^{r}\left[\frac{\left|X_{i, j}-X_{j}\right|}{X_{j}}\right]\right]
$$

Where:

$n$ is the number of otoliths, $r$ is the total number of readings,

$X_{i, j}$ is the number of rings in otolith $j$ in reading $i$, and

$X_{j}$ is the average number of rings in $r$ readings.

We also plotted the expected probability of disagreement (PD) and the mean magnitude of inter-read discrepancy (IRD) by age in order to explore tendencies in ageing error (Marriott \& Mapstone, 2006). 


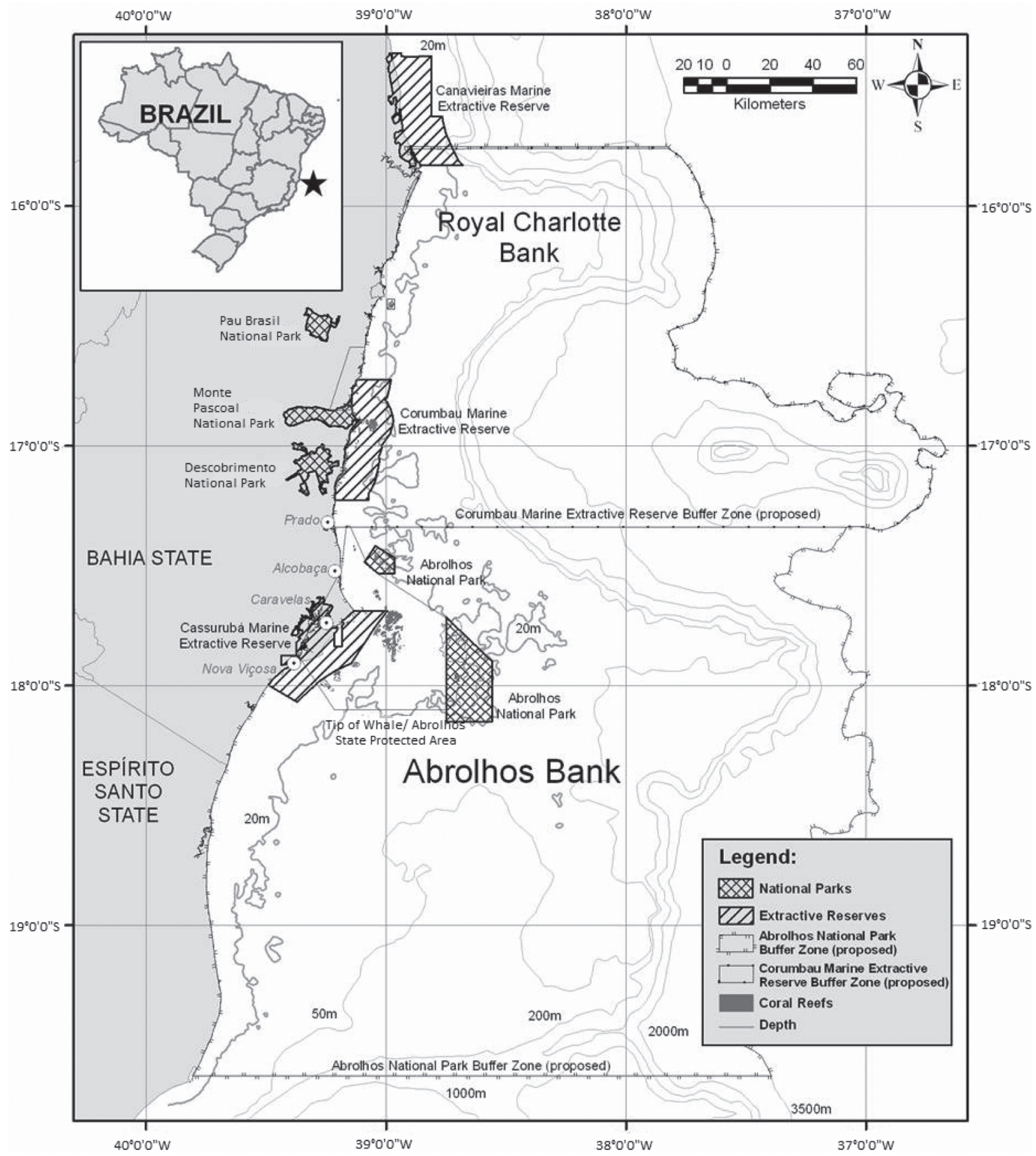

Fig. 1. Abrolhos Bank, Northeastern Brazil, showing the marine protected areas.

Marginal increment for otoliths from fish smaller than 60 $\mathrm{cm}$ and with three or more rings $(\mathrm{n}=110)$ was computed as an attempt to validate growth rings. Larger otoliths may have smaller marginal increments (Claro et al., 1999) and therefore were not used.
The growth in length was modeled using the von Bertalanffy growth function (VBGF, Beverton \& Holt, 1957), where the expected size at a given age $a$ is $L_{a}$ given by:

$$
\text { (2) } L_{a}=L_{\infty}\left\lfloor 1-e^{-K\left(a-t_{0}\right)}\right\rfloor
$$


Where:

$a$ is the age of the fish, assumed here equivalent to a ringgroup (year, explanatory variable),

$L_{a}$ is the furcal length of fish with age $a(\mathrm{~cm}$, response variable),

$L_{\mathrm{oo}}$ is the asymptotic length (cm, parameter of the function),

$K$ is the growth rate constant (year ${ }^{-1}$, parameter of the function),

$t_{0}$ is the age when length is theoretically zero (year, parameter of the function).

The observed length-at-age $L_{a, j}$ for an individual fish $j$ in the sample is:

$$
\text { (3) } L_{a, j}=L_{a}+\varepsilon_{a, j}
$$

Where $\varepsilon_{a, j}$ is the residual. The residuals were assumed to have a normal distribution.

Two error assumptions were considered for the residuals: constant variance (SBV):

$$
\text { (4) } \varepsilon_{a, j} \sim N\left(0, \sigma^{2}\right)
$$

and constant coefficient of variation (CVVB):

$$
\text { (5) } \varepsilon_{a, j} \sim N\left(0, C V^{*} L_{a}\right)
$$

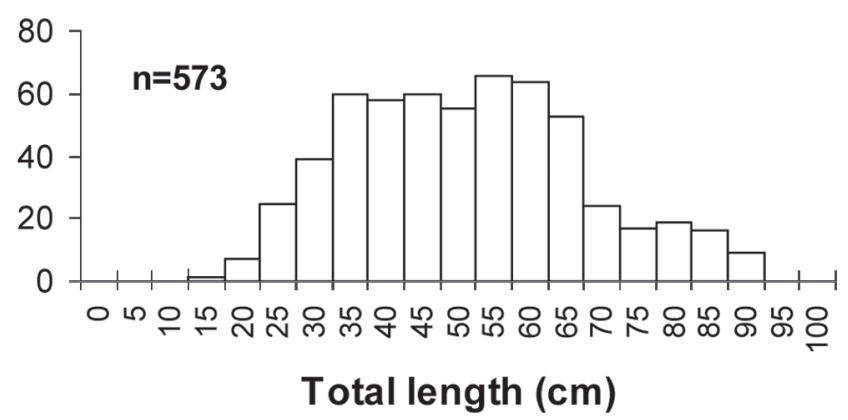

Fig. 2. Size distribution of specimens of Lutjanus jocu from Abrolhos Bank, captured by the commercial fishing fleet.

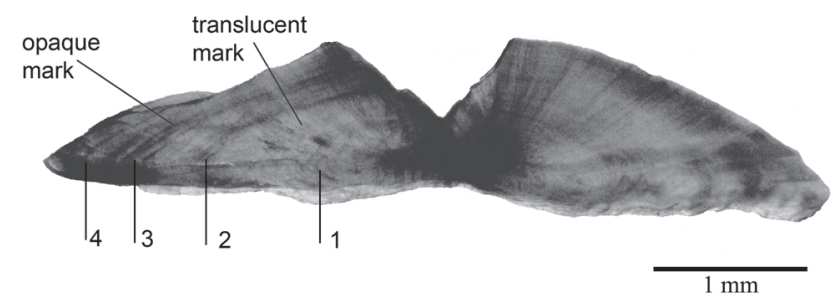

Fig. 3. Sectioned otolith of Lutjanus jocu under transmitted light showing the opaque marks (numbered rings) and translucent bands observed (Photo by M. Previero).
Where CV is the coefficient of variation of length at a given age.

The models were estimated using R 2.10.1 (SVB, nls routine) and ADMB (CVVB, Cope \& Punt, 2007). Growth parameters were also estimated separately for males and females with the assumption of constant variance (Claro et al., 1999). The curves were compared using Kimura's likelihood Ratio Test (Haddon, 2001) or the Akaike Information Criterion (AIC, Burnham \& Anderson, 1998). The models with the lowest AIC are more plausible. Burnham \& Anderson (1998) suggest considering models with $\Delta_{i} \leq 2$ for inferences, where $\Delta_{i}$ is the difference between the AIC of the model in consideration and that the best fitting model. Models with $\Delta_{i}$ between 4 and 7 have less empirical support and with $\Delta_{i}$ larger than 10 fail to explain substantial empirical variability.

The relationship between fork length (FL) and total weight (TW) was established through the mathematical expression proposed by Le Crên (1951):

$$
\text { (6) } T W=\alpha F L^{\beta}
$$

Where $a$ and $b$ are parameters.

In addition, observations were made about the relationship between lengths and weights for males and females.

\section{Results}

Larger fish were caught with harpoon $(19-89 \mathrm{~cm})$, long line $(27-85 \mathrm{~cm})$ or hand lines $(17-90 \mathrm{~cm})$, while small fish were captured with gillnets in the estuaries $(15-44 \mathrm{~cm})$.

There was no significant difference between the weight of right and left otoliths $(\mathrm{df}=177$; paired t-test $=0.825 ; \mathrm{p}=$ 0.205 ). Readings of whole otoliths were not consistent with those of sectioned otoliths due to increased opacity towards the center.

Table 1. Frequency distribution of fish fork length (FL) by age (years) of the dog snapper Lutjanus jocu from Abrolhos Bank.

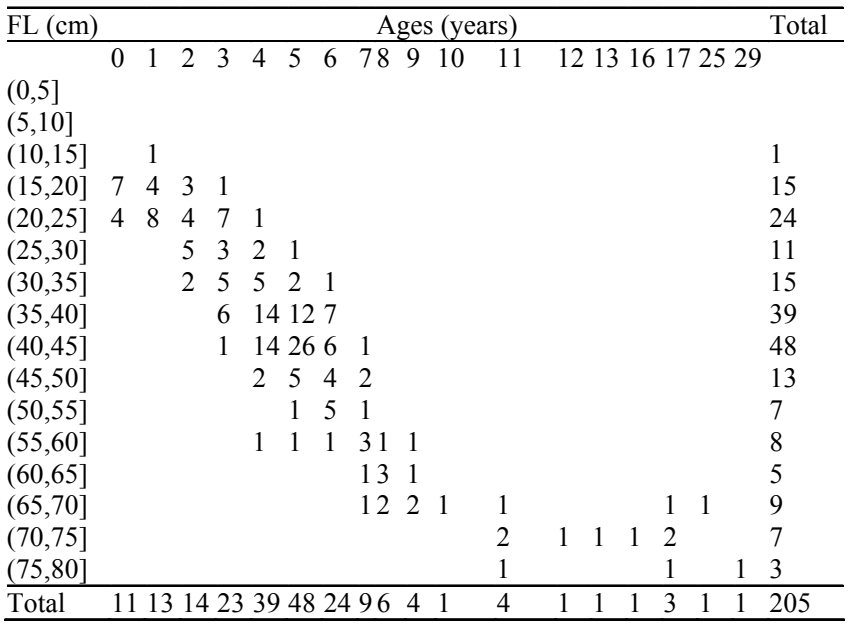


From the readings in the sectioned otoliths it was observed that the mean age rings was 4.7 and 5.3 for females and males, respectively. Most aged specimens (88.3\%) had between 0 and 7 years (Table 1). Few individuals were older than 10 years and the maximum age recorded was 29 years. Fish larger than $60 \mathrm{~cm}$ were 7 years or older.

The index of average percent error (APE) between the two readings of sectioned otoliths was $11.7 \%$. The percent disagreed ages (PD) increased from age 0 to 2 and leveled off thereafter (Fig. 4). Mean inter-read discrepancy (IRD) was relatively stable between 1 and 2 rings for all ages, with the exception of the oldest animal, for which the IRD was 4 (Fig. 5).

We were not able to validate growth increments for the whole sampling period, due to uneven sampling for the smaller size classes (Fig. 6). However, based on other studies from this species (Claro et al., 1999; Rezende \& Ferreira, 2004), we assumed that age rings are annual.

The parameters of the von Bertalanffy growth function for dog snappers from Abrolhos Bank, estimated with the assumption of constant variance and constant $\mathrm{CV}$, had marked differences. The estimate of $L_{\mathrm{oo}}$ was smaller and the estimate of $K$ was larger for the constant variance model, when compared with the constant coefficient of variation model (Table 2). The model with constant CV had higher empirical

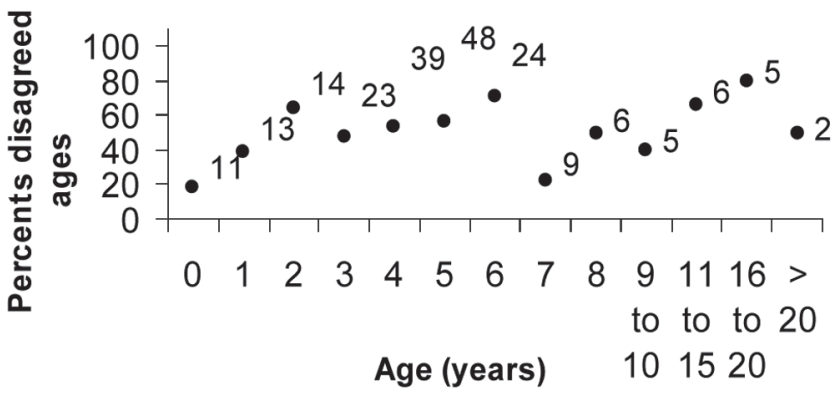

Fig. 4. Observed percentages of samples for which the first and second readings disagreed of the dog snapper Lutjanus jocu from Abrolhos Bank. Age is the first reading (number of rings). The numbers represent the sample size. Older ages were pooled due to the small sample size.

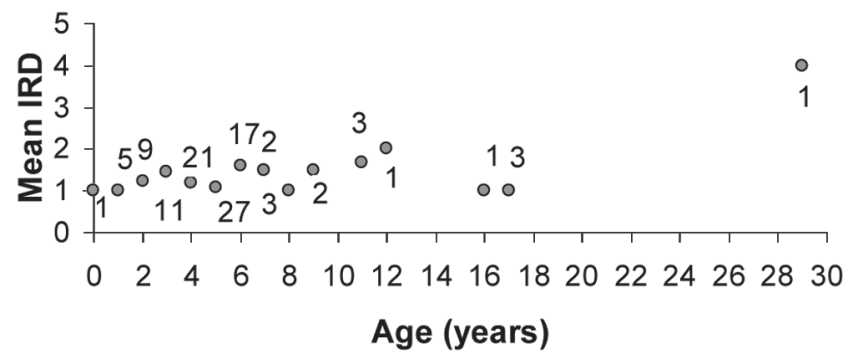

Fig. 5. Observed mean inter-read discrepancy (IRD). Age is the first reading (number of rings) of the dog snapper Lutjanus jocu from Abrolhos Bank. The numbers represent the sample size. support $(\mathrm{AIC}=1849.954, \mathrm{df}=4)$ than the constant variance model $(\mathrm{AIC}=2240.135, \mathrm{df}=4)$. All growth curves had similar shapes up until 15 years and differed afterward (Fig. 7). The models fit to the two reading and to the average age had similar estimates for all parameters. For the average age reading and constant variance, we also tested a model with $t_{0}$ set equal to zero ( $\mathrm{AIC}=2336.748, \mathrm{df}=3$ ) which had a worse fit than the model with free $t_{0}(\mathrm{AIC}=2240.135, \mathrm{df}=4)$.

The estimate of $L_{\mathrm{oo}}$ found for males was higher than that found for females, while the estimate of $K$ was larger for females than for males (Table 3). The growth curves of each sex were significantly different according to Kimura's likelihood Ratio Test $\left(\chi^{2}=28.076, \mathrm{df}=3, \mathrm{p}<0.000009\right)$ (Fig. 8).

The relationship between fork length (FL) and total weight (TW) was established showing that the growth of dog snapper is isometric ( $\mathrm{TW}=0.020 \mathrm{FL}^{2.9679}$ ), the standard error of the exponent is $=0.155, \mathrm{t}=-1.478$ for $\mathrm{H}_{0}=3, \mathrm{n}=300$ (Fig. 9). No significant differences for the length-weight relationship by sex were found. The average fork length was $35.37 \mathrm{~cm}$ for

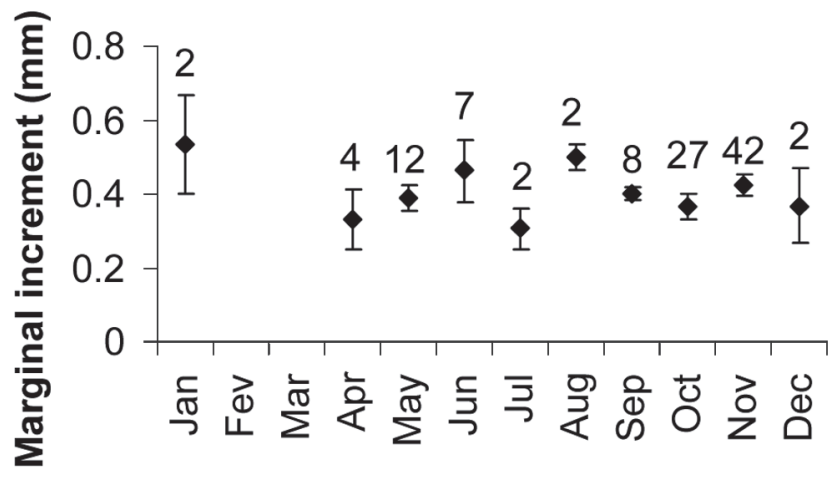

Fig. 6. Monthly measures of the marginal increment in the otoliths of the dog snapper Lutjanus jocu for the year 2006 in Abrolhos Bank. The numbers represent the sample size.

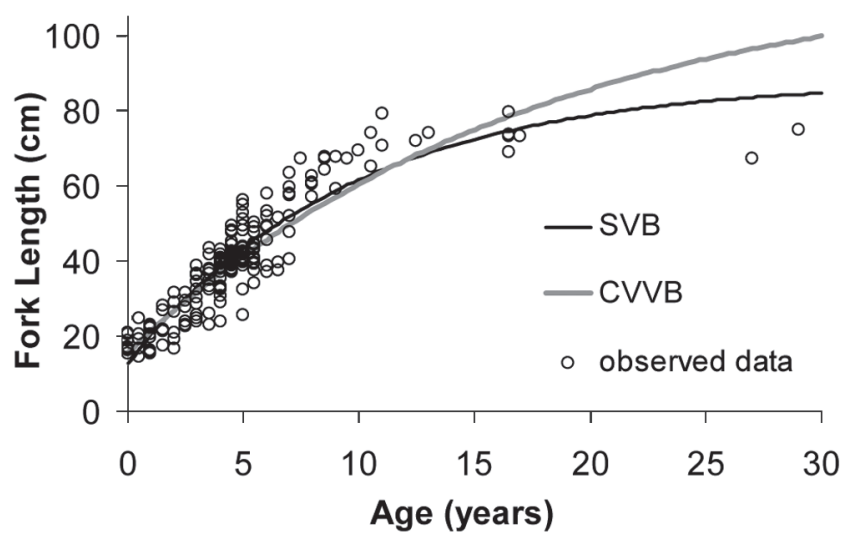

Fig. 7. Von Bertalanffy growth curves fitted to length-at-age from sectioned otoliths data for both sexes of the dog snapper Lutjanus jocu from Abrolhos Bank, with two assumptions: $\mathrm{SVB}=$ Constant variance for all ages and $\mathrm{CVVB}=$ Constant coefficient of variation for all ages. 
Table 2. Von Bertalanffy growth parameters estimate of the dog snapper Lutjanus jocu from Abrolhos Bank. $t_{0}$ is significantly different from zero, $\mathrm{SVB}=$ Constant variance for all ages, $\mathrm{CVVB}=\mathrm{Constant}$ coefficient of variation for all ages and $\mathrm{se}=$ Standard error.

\begin{tabular}{llrlcccc}
\hline Model & reading & $L_{\alpha}$ & $\mathrm{se}\left(L_{\mathrm{\alpha}}\right)$ & $K$ & $\mathrm{se}(K)$ & $t_{0}$ & $\mathrm{se}\left(t_{0}\right)$ \\
\hline SVB & 1 & 87.7 & 4.349 & 0.1035 & 0.0106 & -1.49 & 0.24 \\
& 2 & 88.7 & 4.640 & 0.0979 & 0.0105 & -1.93 & 0.25 \\
& average & 87.8 & 3.944 & 0.1052 & 0.0097 & -1.49 & 0.21 \\
CVVB & 1 & 117.8 & 18.878 & 0.0580 & 0.0130 & -2.58 & 0.22 \\
& 2 & 112.8 & 16.775 & 0.0610 & 0.0130 & -2.83 & 0.23 \\
& average & 117.6 & 16.699 & 0.0600 & 0.0120 & -2.47 & 0.19 \\
\hline
\end{tabular}

Table 3. Von Bertalanffy growth parameters estimates for female and males of the dog snapper Lutjanus jocu from Abrolhos Bank. The age is the average age between reading 1 and 2 (se $=$ Standard error $)$.

\begin{tabular}{lcccccc}
\hline Sex & $L_{\infty}$ & $\operatorname{se}\left(L_{\infty}\right)$ & $K$ & $\operatorname{se}(K)$ & $t_{0}$ & $\operatorname{se}\left(t_{0}\right)$ \\
\hline Female & 82.093 & 4.785 & 0.105 & 0.013 & -1.575 & 0.302 \\
Male & 92.788 & 6.083 & 0.099 & 0.013 & -1.686 & 0.297 \\
\hline
\end{tabular}

Table 4. Regressions among size variables (TL - Total length, FL - Fork length, SL - Standard length in cm; TW - Total weight in $\mathrm{g} ; \mathrm{n}=204)$. Size range $(\mathrm{TL}=15.5-83.0 ; \mathrm{FL}=14.5$ 79.5 , and $\mathrm{SL}=12.0-69.5)$ and weight range (60.0 - 8365.0) of the dog snapper Lutjanus jocu from Abrolhos Bank.

\begin{tabular}{lcc}
\hline Variables & \multicolumn{1}{c}{ Equation } & $\mathrm{R}^{2}$ \\
\cline { 1 - 2 } TL-FL & $\mathrm{TL}=1.0942 \mathrm{FL}^{1.0044}$ & 0.99 \\
TL-SL & $\mathrm{TL}=1.5106 \mathrm{SL}^{0.9485}$ & 0.97 \\
FL-TL & $\mathrm{FL}=0.9859 \mathrm{SL}^{0.9865}$ & 0.99 \\
FL-SL & $\mathrm{FL}=1.449 \mathrm{SL}^{0.9421}$ & 0.98 \\
SL-TL & $\mathrm{SL}=0.717 \mathrm{FL}^{1.0265}$ & 0.97 \\
SL-FL & $\mathrm{SL}=0.7364 \mathrm{FL}^{1.0372}$ & 0.98 \\
TW-TL & $\mathrm{TW}=4.1723 \mathrm{TL}^{0.3298}$ & 0.96 \\
TW-FL & $\mathrm{TW}=3.9886 \mathrm{FL}^{0.32 / 1}$ & 0.96 \\
TW-SL & $\mathrm{TW}=0.0609 \mathrm{SL}^{2.7941}$ & 0.96 \\
\hline
\end{tabular}

females $(\mathrm{n}=125)$ and $44.02 \mathrm{~cm}$ for males $(\mathrm{n}=178)$. The average weight was $1197.40 \mathrm{~g}$ and $2078.70 \mathrm{~g}$ for females and males, respectively. Conversions between the various measures of weight and length are presented in Table 4 , as is $\mathrm{r}^{2}$ (almost 1.0 in most cases).

\section{Discussion}

Sagittae otoliths of $L$. jocu are robust and thick in the core region and thin in the extremities. Otoliths of younger fish grow primarily in length, but from 8 years on there is a noticeable increase in thickness (Rezende \& Ferreira, 2004), compromising the count of rings without sectioning. For instance, our readings of whole otoliths for fish between 0 and 6 years tended to overestimate age estimates when compared to those of sectioned otoliths. We were unable to distinguish growth rings for fish older than 6 years when

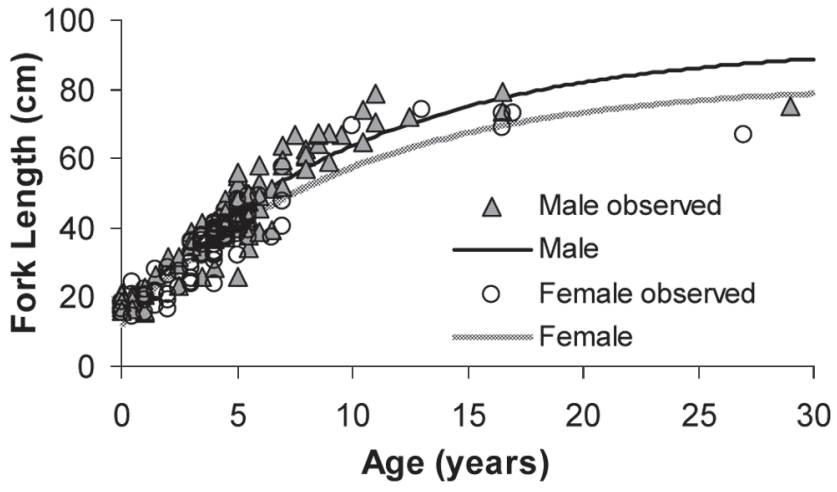

Fig. 8. Von Bertalanffy growth curves for males and females fitted to length-at-age from sectioned otoliths using the constant variance assumption for the dog snapper Lutjanus jocu from Abrolhos Bank.

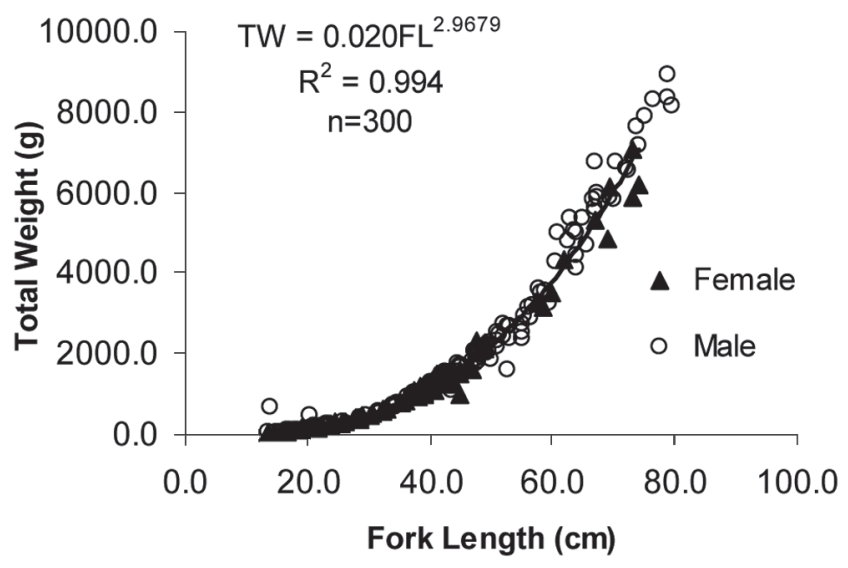

Fig. 9. Length-weight relationship for males and females of the dog snapper Lutjanus jocu from Abrolhos Bank.

reading whole otoliths, and this fact was also reported by (Rezende \& Ferreira, 2004). Therefore, readings of whole otoliths were further dismissed, and we only present age estimates based on sectioned otoliths.

Average percent error index was $11.7 \%$, which corresponds to a CV of $16.0 \%$ (conversion factor provided by Campana, 2001), which is a value within the range of what is found in the literature reviewed by Campana (2001). Although Campana (2001) suggests that a CV of $5.5 \%$ should be aimed for in growth studies, his review of more than one hundred studies using several ageing structures revealed that the median $\mathrm{CV}$ was $7.6 \%$ (corresponding to an APE of 5\%) and may be as high as $26 \%$. The mean inter-read discrepancy (IRD) for this study is around one and increases in the age group between 20 and 30 years is about 4 , which is similar to what has been reported for other Lutjanus species (Marriott \& Mapstone, 2006). The fits of the growth models to the two readings and to the average age showed similar results, indicating that the level of precision does not influence the estimates of the 
growth curve parameters as much as other characteristics of the data.

Otolith ring formation was considered annual. Sampling of individuals occurred for a long period (May 2005 to April 2007); however, the number of specimens collected each month was relatively low, and for some months no fish were available for sampling, hindering the determination of the time and frequency of ring formation in otoliths for the whole period. For 2006, it seems that the smallest growth increments occurred either in May or July; however, the sample size in those months was too small to allow for a conclusive time of ring formation. Rezende (2008) and Claro et al. (1999) determined that the formation of rings for Lutjanus jocu is annual and occurs in June and July in Pernambuco State (Brazil) (Southern Hemisphere winter, 08 03'14" latitude) and in April in Cuba (Northern Hemisphere spring). Several other authors have found that the snappers have one annual ring formation (e.g., Cappo et al., 2000; Newman et al., 2000a, 2000b; Burton, 2002).

Two assumptions of variance of length-at-age were used to fit the growth model. The estimates of the parameters using constant variance of length-at-age (SVB) for aggregated sex were quite similar to the value estimated from this species from northeastern coast of Brazil (Rezende \& Ferreira, 2004). The SVB parameter estimates for separated sexes were very similar to those found in Cuban waters (Claro et al., 1999) (Table 5).

The assumption of constant coefficient of variation (CVVB) indicates that the $L_{\mathrm{oo}}$ should be both higher than what was estimated for the SVB model and than what has been reported in the literature (Claro et al., 1999; Rezende \& Ferreira, 2004; Rezende, 2008). With increasing age, the variance of length-at-age also increases and $L_{\mathrm{oo}}$ is estimated to be much higher than the size of the older fish in our sample. Although this estimate of $L_{\text {oo }}$ may seem unrealistic, there is evidence that Lutjanus jocu may attain larger sizes (Table 5) and that it might have a higher growth potential than has been reported. The largest specimens reported by Klippel et al. (2005) from the Vitória fleet in the region of Abrolhos Bank was $115 \mathrm{~cm}$ FL. The largest Lutjanus jocu sampled by Martins et al. (2005) in the same region in a scientific survey was 97 $\mathrm{cm} \mathrm{TL}(=90.60 \mathrm{FL})$. Further north $\left(2^{\circ}\right.$ to $\left.13^{\circ} \mathrm{S}\right)$ Nóbrega \& Lessa
(2007) reported that the maximum size found for L.jocu was $103 \mathrm{~cm} \mathrm{TL}(=96.2 \mathrm{~cm} \mathrm{FL})$.

Growth studies from samples held in commercial fisheries landings have higher chances of obtaining skewed results (Ricker, 1969; Haddon, 2001). This is because the growth parameters vary within a species and the fishers use selective fishing gear that tends to capture larger individuals regardless of their age. Individuals that grow rapidly may have higher probability to be caught before they become old, which may prevent the estimation of the size they would have reached at older ages, as well as the potential average asymptotic size for the population (Sainsbury, 1980). The estimated growth rate would be overestimated due to the selective mortality of the fast growing individuals (Sainsbury, 1980). Another source of bias may be the survival rate; the smaller fish would have higher survival rates under selective mortality than the average population (Sinclair et al., 2002). The fishing gears used to catch dog snappers in Abrolhos Bank are highly selective; most individuals captured are between 35 and 65 $\mathrm{cm}$ FL. For this study, the sample was incremented with small fish from the estuaries, which helped to estimate the variability of length-at-age at juvenile ages; however, larger animals were rare in our sample. Besides the potential bias of the gear, there is a known size gradient of Lutjanus jocu from the estuaries to the outer shelf (unpublished data). The fishing fleet that was sampled in our study operates close to shore and in shallow areas (Freitas et al., 2009) which is the habitat of smaller individuals (unpublished data). It seems that the assumption of constant $\mathrm{CV}$ may help to overcome these biases and estimate asymptotic length closer to the largest animals, and not overestimate the growth rate. The estimates of the growth parameters obtained with the assumption of constant $\mathrm{CV}$ may be closer to what is the growth potential for the species, while the estimates obtained with the assumption of constant variance best describe the growth pattern of the population available to harvest by the studies of fishing fleets (Taylor et al., 2005).

The difference between the growth of males and females was most evident in the estimates of $L_{\mathrm{oo}}$ than in the estimates of the other parameters $\left(K\right.$ and $\left.t_{0}\right)$. Claro et al. (1999) found the same difference in the estimate of $L_{\mathrm{oo}}$, with males being about $10 \mathrm{~cm}$ larger than females. Among lutjanids, larger sizes

Table 5. Von Bertalanffy growth parameters estimates and maximum length reported in the literature for the dog snapper Lutjanus jocu. $\mathrm{FL}=$ Fork length and $\mathrm{TL}=$ Total length.

\begin{tabular}{lccccc}
\hline References & $L_{\infty}$ & $K$ & $t_{0}$ & Maximum Length $(\mathrm{cm})$ & Comments \\
\hline Rezende \& Ferreira (2004) & 77.2 & 0.110 & -3.73 & $105 \mathrm{FL}$ & Sectioned otoliths \\
& 84.1 & 0.080 & -5.40 & - & Whole otoliths \\
& 71.2 & 0.112 & -4.32 & - & Back-cal culation \\
Rezende (2008) & 75.5 & 0.140 & -2.71 & $92.2 \mathrm{TL}(=86.2 \mathrm{FL})$ & - \\
Claro et al. $(1999)$ & 85.4 & 0.103 & -2.01 & $72 \mathrm{FL}$ & Female, back-calculation \\
Claro et al. $(1999)$ & 96.4 & 0.085 & -2.14 & $77 \mathrm{FL}$ & Male, back-calculation \\
Klippel et al. (2005) & 118.0 & 0.119 & - & $115 \mathrm{FL}$ & - \\
Nóbrega \& Less a (2007) & - & - & - & $103 \mathrm{TL}(=96.2 \mathrm{FL})$ & - \\
Martins et al. $(2005)$ & - & - & - & $97 \mathrm{TL}(=90.6 \mathrm{FL})$ & - \\
\hline
\end{tabular}


of females have been observed in Atlantic, Caribbean, Hawaiian, and Arabian Gulf species (Grimes, 1987; Grandcourt et al., 2006), but this does not seem to be the standard for the genera, since this study had significantly more males than females, and the same was recorded for several species of the genus Lutjanus in the Indo Pacific (e.g., McPherson \& Squire, 1992; Newman et al., 1996, 2000a, 2000b; Newman, 2002) and other species of reef fish in Brazil (e.g., Haemulon plumierii by Araujo \& Martins, 2007).

Freitas et al. (2011) report a length of first maturation for Lutjanus jocu $\left(L_{50}\right)$ of $32.42 \mathrm{~cm}(\mathrm{se}=0.49)$ for females and $34.42 \mathrm{~cm}(\mathrm{se}=0.74)$ for males, which implies that the age of first maturation may range from 2 to 6 years old, or an average of three years for both males and females. In Cuba, Claro et al., (1999) report that the age of first maturation is around 4-5 years.

Although the methods used here may provide accurate estimates of growth parameters regardless of the small sample size for large animals, it is not possible, with this sample, to estimate the age structure of the population in the entire Abrolhos Bank, and therefore estimate the fishing mortality in the region, because of the evidence that part of the population may be in deeper water where the sampled fleet does not operate. We suggest that for a complete estimate of the age structure within the Abrolhos Bank, the fleet that fish in the coastal areas, such as the one that uses the landing sites sampled by us between 2005 and 2007, and the fleet that operates in the deeper areas of Abrolhos Bank, such as the one that uses the landing sites sampled during the REVIZEE program between 1997 and 2000 (Klippel et al., 2005), should be monitored simultaneously.

\section{Acknowledgements}

We are grateful to Antonio Olinto da Silva, Juliana Kolling, and Mariana Botelho (Instituto de Pesca de São Paulo), Angela Ambrósio, Juliane Cebola, Sílvia Barbosa (Nupélia - Núcleo de Pesquisas em Limnologia, Ictiologia e Aquicultura), Guilherme F. Dutra, Danilo L. Araújo (Conservation International Brazil, Marine Program), Juliana Fonseca (Universidade Estadual "Júlio de Mesquita Filho"), Paulo Costa (Universidade Federal do Estado do Rio de Janeiro), Luis Frota (Instituto Chico Mendes de Conservação da Biodiversidade), Beatrice Ferreira and Sergio Rezende (Universidade Federal de Pernambuco) and Mauricio Hostim-Silva (Universidade Federal do Espírito Santo). We thank Nupélia/Universidade Estadual de Maringá and Conservation International for lab and logistic support. This project was benefited from Conservation Leadership Program (CLP), National Geographic Society grant (to E. Sala), Fundação de Amparo à Pesquisa do Estado da Bahia (to M. Oliveira Freitas), and Conselho Nacional de Desenvolvimento Científico e Tecnológico CNPq-Brazil grants (to C. V. Minte-Vera and M. Previero). This is a contribution of Conservation International's Marine Management Areas Science Program, Brazil Node.

\section{Literature Cited}

Allen, G. R. 1985. FAO fishes catalogue vol. 6. Snappers of the world. An annotated and illustrated catalogue of lutjanid species known to date. FAO Fish Synopsis, 125 vol. 6. 208 p.

Araújo, J. N. \& A. S. Martins. 2007. Age, growth and mortality of white grunt (Haemulon plumierii) from the central coast of Brazil. Scientia Marina, 71: 793-800.

Beamish, R. J. \& D. A. Fournier. 1981. A method for comparing the precision of a set of age determinations. Canadian Journal of Fisheries Aquatic Sciences, 38: 982-983.

Beverton, R. J. H. \& S. J. Holt. 1957. On the dynamics of exploited fish populations. U. K. Ministry of Agriculture, Fisheries and Food, Fishery Investigations Series II, 19: 533p.

Burnham, K. P. \& D. R. Anderson. 1998. Model selection and inference: A practical information-theoretical approach. New York, Springer-Verlag, 353p.

Burton, M. L. 2002. Age, growth and mortality of mutton snapper, Lutjanus analis, from east coast of Florida, with a brief discussion of management implications. Fisheries Research, 59: 31-34.

Campana, S. E. 2001. Accuracy, precision and quality control in age determination, including a review of the use and abuse of age validation methods. Journal of Fish Biology, 59: 197242.

Cappo, M., P. Eden, S. J. Newman \& S. Robertson. 2000. A new approach to tetracycline validation of the periodicity and timing of increment formation in the otoliths of 11 species of Lutjanus from the central Great Barrier Reef. Fisheries Bulletin, 98: 474488.

Claro, R., L. M. Sierra-Sierra \& J. P. García-Artega. 1999. Biologia del jocu, Lutjanus jocu (Bloch y Schneider, 1801) (Pisces: Lutjanidae) em las zonas NE y SW de la plataforma cubana, II. Alimentación, edad y crecimiento. Revista Investigaciones Marinas, 20: 30-38.

Cope, J. M. \& A. E. Punt. 2007. Admitting ageing error when fitting growth curves: an example using the von Bertalanffy growth function with random effects. Canadian Journal of Fisheries Aquatic Sciences, 64: 205-218.

Costa, P. A. S., A. C. Braga \& L. O. F. Rocha. 2003. Reef fisheries in Porto Seguro, eastern Brazilian coast Fisheries Research. Fisheries Research, 60: 77-583.

Frédou, T. \& B. Ferreira. 2005. Bathymetric Trends of Northeastern Brazilian Snappers (Pisces, Lutjanidae): Implications for the Reef Fishery Dynamic. Brazilian Archives of Biology and Technology, 48: 787-800.

Frédou, T., B. P. Ferreira \& Y. Letourneur. 2009a. Assessing the stocks of the primary snappers caught in Northeastern Brazilian reef systems. 1: Traditional modelling approaches. Fisheries Research, 99: 90-96.

Frédou, T., B. P. Ferreira \& Y. Letourneur. 2009b. Assessing the stocks of the primary snappers caught in Northeastern Brazilian reef systems. 2 - A multi-fleet age-structured approach. Fisheries Research, 99: 97-105.

Freitas, M. O. 2009. Pesca artesanal e biologia reprodutiva do ariocó Lutjanus synagris (Lutjanidae) no Banco dos Abrolhos. Unpublished M.Sc. Dissertation. Universidade Estadual de Santa Cruz, Ilhéus, 126p.

Freitas, M. O., R. L. Moura, R. B. Francini-Filho \& C.V. MinteVera. Spawning patterns of commercially important reef fishes (Lutjanidae and Serranidae) in the tropical Western South Atlantic. Scientia Marina, 75(1): 135-146. 
Grandcourt, E. M., T. Z. Abdessalaam \& F. Francis. 2006. Age, growth, mortality and reproduction of the blackspot snapper, Lutjanus fulviflamma (Forsskal, 1775), in the southern Arabian Gulf. Fisheries Research, 78: 203-210.

Grimes, C. B. 1987. Reproductive biology of the Lutjanidae: a review. Pp. 239-294. In: Polovina, J. J. \& S. Ralston (Eds.). Tropical snappers and groupers: biology and fisheries management. Boulder, Colorado, Westview Press, 659p.

Haddon, M. 2001. Modelling and quantitative methods in fisheries. London, Chapman \& Hall, 406p.

IBAMA. 2007. Boletim estatístico da pesca marítima e estuarina do Nordeste do Brasil - 2005. Centro de Pesquisa e Gestão de Recursos Pesqueiros do Litoral Nordeste - Tamandaré, IBAMA/ CEPENE, 78p.

Klippel, S., G. O. Paulo, A. S. Costa, A. S. Martins \& M. B. Peres. 2005. Avaliação dos estoques de lutjanídeos da costa central do Brasil: análise de coortes e modelo preditivo de Thompson e Bell para comprimentos. Pp. 83-98. In: Costa, P. A. S., A. S. Martins \& G. Olavo (Eds.). Pesca e potenciais de exploração de recursos vivos na região central da Zona Econômica Exclusiva brasileira. Série Livros - Documentos REVIZEE - Score Central. Museu Nacional do Rio de Janeiro, Rio de Janeiro, $248 \mathrm{p}$.

Lai, H. L., V. F. Gallucci, D. R. Gunderson \& R. F. Donnelly. 1996. Age determination in fisheries: Methods and applications to stock assessment. Pp. 82-170. In: Gallucci, V. F., S. B. Saila, D. J. Gustafson \& B. J. Rothschild (Eds.). Stock assessment quantitative methods and applications for small-scale fisheries. Boca Raton, Florida, Lewis Publishers, 527p.

Leão, Z. M. A. N., R. K. P. Kikuchi \& V. Testa. 2003. Corals and coral reefs of Brazil. Pp. 9-52. In: Cortes, J. (Ed.). Latin America Coral Reefs. Amsterdam, Elsevier Science.

Le Crên, E. D. 1951. The length-weight relationship and seasonal cycle in gonadal weight and condition in the perch (Perca fluviatilis). Journal of Animal Ecology, 20: 201-219.

Manickchand-Heileman, S. C. \& D. A. T. Philipp. 1996. Reproduction, age and growth of the Caribbean red snapper (Lutjanus purpureus) in waters of Trindade and Tobago. Pp. 137- 149. In: Arreguín-Sanchez, F., J. L. Munro, M. C. Balgos \& D. Pauly (Eds.). Biology, fisheries and culture of tropical groupers and snappers. ICLARM Co. Proc nf. Campeche, Mexico, 48: 449p.

Marriott, R. J. \& B. D. Mapstone. 2006. Consequences of inappropriate criteria for accepting age estimates from otoliths, with a case study for a long-lived tropical reef fish. Canadian Journal of Fisheries and Aquatic Sciences, 63(10): 2259-2274.

Martins, A. S., G. Olavo \& P. A. S. Costa. 2005. Recursos demersais capturados com espinhel de fundo no talude superior da região entre Salvador (BA) e o Cabo de São Tomé (RJ). Pp. 109-128. In: Costa, P. A. S., A. S. Martins \& G. Olavo (Eds.). Pesca e potenciais de exploração de recursos vivos na região central da Zona Econômica Exclusiva brasileira. Rio de Janeiro, Museu Nacional, (Série Livros n. 13).

McPherson, G. R. \& L. Squire. 1992. Age and growth of three dominant Lutjanid species of the Great Barrier Reef inter-reef fishery. Asian Fisheries Science, 5: 25-36.

Monteiro, D. P., T. Giarrizzo \& V. Isaac. 2009. Feeding ecology of juvenile dog snapper Lutjanus jocu (Bloch \& Shneider, 1801) (Lutjanidae) in intertidal mangrove creeks in Curuçá estuary (North Brazil). Brazilian Archives of Biology and technology, 52(6): 1421-1430.
Moura, R. L. \& K. C. Lindeman. 2007. A new species of snapper (Perciformes: Lutjanidae) from Brazil, with comments on the distribution of Lutjanus griseus and L. apodus. Zootaxa, 1422: 31-43.

Newman, S. J. 2002. Growth rate, age determination, natural mortality and production potential of the scarlet seaperch, Lutjanus malabaricus Schneider 1801, off the Pilbara coast of north-western Australia. Fisheries Research, 58(1801): 215-225.

Newman, S. J., M. Cappo \& D. McB. Williams. 2000a. Age, growth, mortality rates and corresponding yield estimates using otoliths of the tropical red snappers, Lutjanus erythropterus, L. malabaricus and L. sebae, from the central Great Barrier Reef. Fisheries Research, 48, 1-14.

Newman, S. J., M. Cappo \& D. McB. Williams. 2000b. Age, growth and mortality of the stripey, Lutjanus carponotatus (Richardson) and the brown-stripe snapper, L. vitta (Quoy \& Gaimard) from the central Great Barrier Reef, Australia. Fisheries Research, 48: 263-275.

Newman, S. J., D. McB. Williams \& G. R. Russ. 1996. Age validation, growth and mortality rates of the tropical snappers (Pisces: Lutjanidae) Lutjanus adetii (Castelnau, 1873) and $L$. quinquelineatus (Bloch, 1790) from the Central Great Barrier Reef, Australia. Marine Freshwater Research, 47: 575-584.

Nóbrega, M. F. \& R. P. Lessa. 2007. Descrição e composição das capturas da frota pesqueira artesanal da região nordeste do Brasil. Arquivos de Ciências do Mar, 40(2): 64-74.

Rezende, S. M. 2008. Evolução das capturas, idade, crescimento e recrutamento de espécies de Lutjanidae do Nordeste do Brasil. Unpublished Ph.D. Dissertation. Universidade Federal de Pernambuco, Recife, 198p.

Rezende, S. M. \& B. P. Ferreira. 2004. Age, growth and mortality of dog snapper Lutjanus jocu (Bloch \& Schneider, 1801) in the northeastern coast of Brazil. Brazilian Journal of Oceanography, 52(2): 107-121.

Ricker, W. E. 1969. Effects of size-selective mortality and sampling bias on estimates of growth, mortality, production and yield. Journal of Fisheries Research Board Canada, 26: 479-541.

Sainsbury, K. 1980. Effect of individual variability on the von Bertalanffy growth equation. Canadian Journal of Fisheries Aquatic Sciences, 37: 241-247.

Secor, D. H., J. M. Dean \& E. H. Laban. 1991. Manual for otolith removal and preparation for microstructure examination. Baruch Institute Technical Report 91-1. Belle W. Baruch Institute, University of South Carolina and Electric Power Research Institute.

Sinclair, A. F., D. P. Swain \& J. M. Hanson. 2002. Disentangling the effects of size selective mortality, density and temperature on length-at-age. Canadian Journal of Fisheries Aquatic Sciences, 59: 372-382.

Taylor, N., C. G. Walters \& S. J. D. Martell. 2005. A new likelihood for simultaneously estimating von Bertalanffy growth parameters, gear selectivity, and natural and fishing mortality. Canadian Journal of Fisheries Aquatic Sciences, 62: 215-223.

Vacchi, M., P. N. Psomadakis, N. Repetto \& M. Würtz. 2010. First record of the dog snapper Lutjanus jocu in the Mediterranean Sea. Journal of Fish Biology, 76: 723-728.

Vasconcellos, M., A. C. Diegues \& R. R. Sales. 2007. Limites e possibilidades na gestão da pesca artesanal costeira. Pp. 15-84. In: Costa, A. (Org.). Nas redes da pesca artesanal. Brasília: IBAMA, PNUD, 1(1).

Accepted January 25, 2011 Published June 30, 2011 